\title{
REVITALISASI NASKAH SYAIR: SEBUAH SOLUSI DALAM PENGEMBANGAN KREATIVITAS MAHASISWA UNTUK MENCINTAI BUDAYA LOKAL
}

\author{
Tuti Andriani \\ Fakultas Tarbiyah dan Keguruan UIN Suska Riau \\ Korespondensi: Jl. Subrantas Km. 15 Pekanbaru 28293 \\ Pos-el: tiadelwys_sweet@yahoo.com
}

\begin{abstract}
Cultures were grown in campus tend to imitate the western culture, so that the local culture is ruled out. The local culture is considered ancient culture, so it does not show up in the form of creativity. Though Indonesia is rich with culture can be preserved in the campus. One of them is a manuscript poem, which is one form of the local culture of our nation. The text of the poem can be in the form of creative songs, drama, dance and others. One solution is to develop student creativity with the revitalization (revive) the text of the poem and developed through programs of student organizations in the field of arts and culture. So it is the first step to develop a sense of love of local culture.
\end{abstract}

Keywords: manuscript poem, student activity, local culture

\begin{abstract}
Abstrak
Budaya yang tumbuh di kampus cenderung meniru budaya barat, sehingga budaya lokal dikesampingkan. Budaya lokal dianggap budaya kuno, sehingga tidak muncul dalam bentuk kreativitas. Padahal Indonesia kaya dengan budaya dapat dipertahankan dalam kampus. Salah satunya adalah puisi naskah, yang merupakan salah satu bentuk budaya lokal bangsa kita.Teks puisi bias dalam bentuk yang kreatiflagu, drama, tari dan lain-lain. Salah satu solusinya adalah dengan mengembangkan kreativitas siswa dengan revitalisasi teks puisi dan dikembangkan melalui program organisasi mahasiswa di bidangsenidanbudaya. Jadi langkah pertama untuk mengembangkan rasa cinta budaya lokal.
\end{abstract}

Kata-kata kunci: naskah syair, kreativitas mahasiswa, budaya lokal

\section{PENDAHULUAN}

Naskah merupakan pembahasan dalam filologi. Filologi ialah suatu ilmu yang obyek penelitiannya naskah-naskah lama. Salah satunya adalah naskah syair. Naskah di sini, ialah semua peninggalan tertulis nenek moyang kita pada kertas, lontar, kulit kayu, dan rotan. Tulisan tangan pada kertas itu biasanya dipakai pada naskah-naskah yang berbahasa Melayu dan yang berbahasa Jawa; lontar bnyak dipakai pada naskah-naskah berbahasa Jawa dan Bali dan kulit kayu dan rotan biasa digunakan pada naskahnaskah berbahasa Batak.

Apabila naskah-naskah tidak dirawat dengan baik akan cepat sekali hancur dan tidak bernilai lagi sebagai warisan budaya nenek moyang.. Naskah itu baru berharga, apabila masih dapat dibaca dan dipahami dan naskah-naskah tersebut masih dianggap sebagai hasil sastra lama Ada yang sebetulnya tidak dapat digolongkan dalam karya sastra, seperti 
undang-undang, adat-istiadat, cara-cara membuat obat, dan cara membuat rumah. Sebagian besar dapat digolongkan dalam karya sastra, dalam pengertian khusus, seperti cerita-cerita dongeng, hikayat, cerita binatang, pantun, syair, gurindam, dsb.

Kreativitas yang berkembang di dunia kampus saat ini , mahasiswa lebih memilih seni dan budaya barat dibandingkan budaya lokal sendiri. Mahasiswa lebih menyukai cerita-cerita dari barat, mendengarkan musik dari barat, bahkan lagu-lagu yang diminati cenderung kepada tema-tema percintaan, patah hati dan lain sebagainya, sehingga mereka mengenyampingkan budaya lokal . Padahal budaya lokal sarat dengan makna sejarah, pendidikan, nasehat, hukum, agama dan lain-lain.

Mahasiswa melupakan budaya lokal bangsanya sendiri, di karenakan mereka menganggap budaya kita kuno dan ketinggalan zaman. Padahal budaya lokal di Indonesia sangat kaya dengan seni sastranya seperti syair-syair yang berisi cerita rakyat, nasehat, kasih sayang dan lain-lain. Naskah syair-syair tersebut bisa dijadikan sebuah kreativitas dalam kegiatan seni mahasiswa di kampus. Oleh karena itu tulisan ini mencoba memberikan sebuah solusi supaya mahasiswa lebih mencintai budaya lokal melalui revitalisasi naskah syair yang ada di dalam budaya kita.

Naskah syair merupakan salah satu karya sastra daerah dan merupakan hasil karya masyarakat Indonesia masa lampau. Menurut Mulyadi (1994) warisan kebudayaan tersebut ada yang dalam bentuk cerita rakyat yang diturunkan dari mulut ke mulut, dan ada yang berbentuk tulisan tangan (naskah).

Basuki (1989) menjelaskan bahwa naskah itu berisi berbagai nilai kehidupan seperti ajaran moral, tradisi, pedoman hidup, dan lain-lain. Dengan kata lain naskah merupakan refleksi kehidupan masyarakat pada zamannya. Naskah- naskah klasik nusantara itu dapat dipandang sebagai salah satu hasil karya sastra sumber lokal yang paling otentik, dan dapat memberikan informasi sejarah dan pemikiran yang pernah berkembang pada kurun waktu tertentu (Bafadal dan Saefullah, 2005).

Begitu pula menurut Abdullah (2006) naskah-naskah klasik Nusantara itu sampai saat ini masih banyak tersimpan di berbagai tempat seperti perpustakaan, museum, baik di dalam maupun di luar negeri. Dalam khazanah sastra klasik Nusantara terdapat naskah berjenis puisi atau syair. Jurji Zildan dalam Muzakki berpendapat bahwa syair berarti nyanyian (al-ghina), lantunan (insyadz), atau melagukan (tartil). Asal kata ini telah hilang dari Bahasa Arab, namun masih ada dalam bahasa lain seperti شور (syuur) dalam bahasa Ibrani yang berarti suara, bernyanyi, dan melantunkan lagu (Muzzaki, 2006).

Waluyo (1987) mengatakan, puisi (syair) adalah karya sastra yang bersifat imajinatif dengan bahasa bersifat konotatif (tersirat) karena banyak digunakan makna kias dan makna lambang (majaz), oleh karena itu bahasa yang dipakai memiliki kemungkinan makna, hal ini akan terjadi pengonsentrasian atau pemadatan bahasa dalam puisi, baik pada struktur fisiknya (luar) maupun pada struktur batinnya (dalam).

Menurut Sunarjo (2001) syair adalah salah satu jenis puisi Melayu lama yang terdiri atas empat larik dan berirama a a a a, setiap bait terdiri atas empat larik yang terdiri atas 9,10, atau 12 suku kata. Bait bait dalam syair biasanya membentuk sebuah cerita.

Pradopo (2005) juga mengatakan bahwa tema syair beragam bentuknya seperti syair bertema kepahlawanan, sosial, sejarah, keteladanan, dll, salah satunya ialah syair bertema romantik. Pada syair romantik biasanya dalam pemaparan alur cerita berbentuk prosa, 
karena prosa itu pada umumnya bersifat bercerita.

Syair romantik merupakan cerita yang bahasanya puitis dan kadangkadang sulit untuk dipahami maknanya selain itu sebagai cerita pelipur lara yang merupakan karya sastra masa lampau yang pada mulanya berbentuk sastra lisan sehingga jenis cerita tersebut bersifat perintang waktu dan menghibur belaka. Aliran romantik menggambarkan kenyataan hidup dengan penuh keindahan. Jika yang dilukiskan kesedihan, maka pengarang ingin agar air mata terkuras. Sebab itu aliran romantik sering dikaitkan dengan sifat sentimental atau cengeng. Kecendrungan menggambarkan keindahan alam, bunga, sungai, tumbuhan, gunung, daun, dan bulan, didasarkan atas kepentingan memperindah kenyataan itu.

Sebagaimana yang sudah dijelaskan di atas, bahwa syair adalah salah satu bentuk puisi lama. Berdasarkan beberapa referensi maka ciri-ciri syair antara lain :

1. Setiap bait terdiri dari empat baris.

2. Setiap baris terdiri atas 8-14 suku kata.

3. Bersajak a-a-a-a.

4. Semua baris adalah isi.

5. Bahasanya biasanya kiasan.

Edwar Djamaris mengemukakan bahwa syair secara garis besar digolongkan menjadi beberapa golongan, di antaranya adalah syair simbolik, syair bertema sejarah, syair cerita panji, syair keagamaan dan syair cerita wayang (Djamaris, 1986). Braginsky (1998) berpendapat bahwa syair merupakan hal yang tidak asing bagi rakyat Melayu.
Perkembangan syair di masyarakat Melayu berdasarkan bentuk persajakan syair sufi. Syair menurut isi, tema, dan tokoh dapat digolongkan menjadi 'syair romantis (percintaan)', 'syair sejarah', 'syair alegoris' (yang sebagian mirip dengan syair percintaan, tetapi tokoh tokoh utamanya ialah bunga, burung, binatang, dan serangga, dan sebagian lagi dengan syair - syair sufi), dan juga 'syair keagamaan', serta 'syair didaktis'. Syair bertema percintaan berkaitan erat dengan syair alegoris, sebab biasanya syair percintaan menggunakan tokoh binatang atau bunga - bungaan. Jenis 'syair romantis' dan 'syair alegoris' umumnya merupakan syair dengan lingkup keindahan bagi pembacanya, namun sebenarnya akan ditemukan semangat jiwa sufi di dalamnya bagi orang yang ingin mengkajinya lebih mendalam. 'Syair sejarah' berada di antara dua lingkup, yakni lingkup faedah dan lingkup keindahan. 'Syair sejarah' tidak kurang keaslian ceritanya, namun juga memperhatikan keindahan dengan unsur sastra yang tinggi. 'Syair alegoris' bisa dikatakan sebagai jenis syair yang terbesar jumlahnya. Semua jenis syair bisa jadi masuk pada jenis 'syair alegoris' meskipun yang terbesar adalah 'syair romantis (percintaan)'. 'syair alegoris' juga mencakup 'syair didaktis' atau unutk menceritakan kisah "kronik kronik skandal" istana secara kiasan (Braginsky, 1998:10).

Berikut ini ada beberapa contoh syair Melayu yang dikenal dengan tunjuk ajar. Syair tunjuk ajar ini merupakan karya Budayawan Melayu Tenas Effendy (2006).

Wahai Ananda Mustika Ayah

Dalam Beriman Janganlah Goyah

Betulkan akal Luruskan Langkah

Mohon Petunjuk Kepada Allah 
Wahai Ananda Buah Hati Bunda Berpegang teguh Kepada Agama Beramalah Engkau Sehabis daya Supaya Selamat dari neraka

Wahai Ananda Bunga Idaman Kenang Olehmu ayah Berpesan Berlaku adil Janganlah segan Bersikap benar Jangan lah Enggan

Wahai Ananda dengarlah Petuah Dalam bergaul janganlah meyalah Dalam bercakap elok Lah lidah Dalam berjalan Luruslah Langkah

Wahai Ananda kuatkan Iman Tunaikan Tugas jalankan Kewajiban Tanggung Jawabmu jangan abaikan Supaya hidupmu diridhoi Tuhan

Wahai ananda dengarlah syair Duduk musyawarah Pantang Menyindir Mufakatkan akal gunakan fikir Supaya kerja tidak Mubazir

Wahai Ananda Intan dikarang Hiduplah engkau berkasih sayang Janganlah suka memusuhi orang Sifat yang buruk hendaklah Buang

Wahai ananda luruskan niat Perangi oleh kerja maksiat Lawan olehmu dengki khianat Mati pun engkau berolah rahmat

Wahai ananda buah hati bunda Hiduplah jujur jangan durhaka Jauhkan bohong haramkan dusta Supaya hidup tiada ternista

Wahai ananda intan dikarang Pegang kokoklah amanah orang Kepercayaan jangan dibuang Supaya hidupmu dijalan terang

Wahai ananda dengarlah petuah Jauhi sifat sombong dan pongah Bergaulah dengan hati merendah Supaya hidupmu berolah berkah 


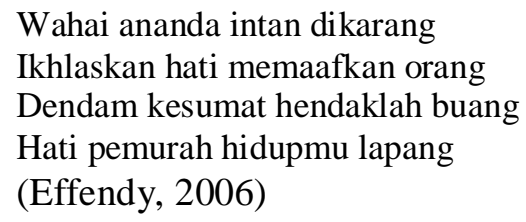

Dari beberapa penjelasan di atas, maka dapat diuraikan bahwa syair menurut isi dibagi menjadi lima golongan, sebagai berikut :

1. Syair Panji.

Syair Panji menceritakan tentang keaadaan yang terjadi dalam istana dan keadaan orang-orang yang berasal dari istana. Contoh syair panji adalah Syair Ken Tambuhan yang menceritakan tentang seorang putri bernama Ken Tambuhan yang dijadikan persembahan kepada Sang Ratu Kauripan.

2. Syair Romantis.

Syair Romantis berisi tentang percintaan yang biasanya terdapat pada cerita pelipur lara, hikayat, maupun cerita rakyat. Contoh syair romantis yakni Syair Bidasari yang menceritakan tentang seorang putri raja yang telah dibuang ibunya. Setelah beberapa lama ia dicari Putra Bangsawan (saudaranya) untuk bertemu dengan ibunya, Pertemuan pun terjadi dan akhirnya Bidasari memaafkan ibunya, yang telah membuang dirinya.

3. Syair Kiasan

Syair Kiasan berisi tentang percintaan ikan, burung, bunga atau buah-buahan. Percintaan tersebut merupakan kiasan atau sindiran terhadap peristiwa tertentu. Contoh syair kiasan adalah Syair Burung Pungguk yang isinya menceritakan tentang percintaan yang gagal akibat perbedaan pangkat, atau seperti perumpamaan "seperti pungguk merindukan bulan".

4. Syair Sejarah.

Syair Sejarah adalah syair yang berdasarkan peristiwa sejarah. Sebagian besar syair sejarah berisi tentang peperangan. Contoh syair sejarah adalah Syair Perang Mangkasar (dahulu bernama Syair Sipelman), berisi tentang perang antara orangorang Makassar dengan Belanda.

5. Syair Agama.

Syair Agama merupakan syair terpenting. Syair agama dibagi menjadi empat yaitu: (a) syair sufi, (b) syair tentang ajaran Islam, (c) syair riwayatcerita nabi, dan (d) syair nasihat.

Setiap syair pasti mengandung pesan tertentu. Pesan tersebut dapat kita simpulkan setelah memahami isi sebuah syair.

\section{BUDAYA LOKAL}

Istilah budaya merupakan kata dasar dari kebudayaan yang artinya: "pikiran; akal budi; adat istiadat; sesuatu mengenai kebudayaan yang sudah berkembang (beradab, maju); sesuatu yang sudah menjadi kebiasaan yang sudah sukar diubah". (Kamus Besar Bahasa Indonesia/KBBI, 2007).

Sedangkan kebudayaan merupakan hasil kegiatan dan penciptaan batin (akal budi) manusia seperti : kepercayaan, kesenian, dan adat istiadat; keseluruhan pengetahuan manusia sebagai makhluk sosial yang digunakan untuk memahami lingkungan serta pengalamannya dan yang menjadi pedoman tingkah lakunya. 
(Kamus Besar Bahasa Indonesia/KBBI, 2007).

Budaya lokal merupakan budaya milik penduduk asli yang merupakan warisan budaya. Jadi budaya lokal adalah kebudayaan yang berlaku dan dimiliki tiap daerah atau suku bangsa. Indonesai dikenal kaya akan corak ragam budaya yang tersebar di berbagai wilayah. Jenis ragam budaya tersebut tercermin dalam adat istiadat, kepercayaan, tradisi, upacara adat, pakaian adat, makan khas daerah, stratifikasi sosial dan lain-lain. Keberagaman tersebut merupakan hasil aktivitas masyarakat yang telah berlansung cukup lama dan kemudian turun temurun kepada generasi berikutnya (Nur Berlian, 2012).

Budaya lokal biasanya didefinisikan sebagai budaya asli dari suatu kelompok masyarakat tertentu. Budaya, satu kata yang tidak dapat dipisahkan dari sebuah negara terlebih untuk Indonesia yang dikenal sebagai negara multikultural. Budaya atau kebudayaan berasal dari bahasa Sansekerta yaitu buddhayah, yang merupakan bentuk jamak dari buddhi (budi atau akal) diartikan sebagai hal-hal yang berkaitan dengan budi dan akal manusia. Budaya tidak dapat dipisahkan dari kehidupan masyarakat karena semua aspek dalam kehidupan masyarakat dapat dikatakan sebagai wujud dari kebudayaan, misalnya gagasan atau pikiran manusia, aktivitas manusia, atau karya yang dihasilkan manusia.

Jacobus Ranjabar mengatakan bahwa dilihat dari sifat majemuk masyarakat Indonesia, maka harus diterima bahwa adanya tiga golongan kebudayaan yang masing-masing mempunyai coraknya sendiri, ketiga golongan tersebut adalah sebagai berikut:

1. Kebudayaan suku bangsa (yang lebih dikenal secara umum di Indonesia dengan nama kebudayaan daerah)

2. Kebudayaan umum lokal

3. Kebudayaan nasional.(Ranjabar, 2006)
Dalam penjelasannya, kebudayaan suku bangsa adalah sama dengan budaya lokal atau budaya daerah. Sedangkan kebudayaan umum lokal adalah tergantung pada aspek ruang, biasanya ini bisa dianalisis pada ruang perkotaan dimana hadir berbagai budaya lokal atau daerah yang dibawa oleh setiap pendatang, namun ada budaya dominan yang berkembang yaitu misalnya budaya lokal yang ada dikota atau tempat tersebut. Sedangkan kebudayaan nasional adalah akumulasi dari budaya-budaya daerah.

Definisi Jakobus itu seirama dengan pandangan Koentjaraningrat (2000). Koentjaraningrat memandang budaya lokal terkait dengan istilah suku bangsa, dimana menurutnya, suku bangsa sendiri adalah suatu golongan manusia yang terikat oleh kesadaran dan identitas akan 'kesatuan kebudayaan'. Dalam hal ini unsur bahasa adalah ciri khasnya.

Menurut Judistira kebudayaan lokal adalah melengkapi kebudayaan regional, dan kebudayaan regional adalah bagianbagian yang hakiki dalam bentukan kebudayaan nasional. Budaya lokal dan budaya nasional, Judistira mengatakan bahwa dalam pembentukannya, kebudayaan nasional memberikan peluang terhadap budaya lokal untuk mengisinya. Adapun definisi budaya nasional yang mempunyai keterkaitan dengan budaya lokal adalah sebagai berikut.

1. Kebudayaan kebangsaan (kebudayaan nasional) berlandaskan kepada puncak-puncak kebudayaan daerah,

2. Kebudayaan kebangsaan ialah gabungan kebudayaan daerah dan unsur-unsur kebudayaan asing,

3. Kebudayaan kebangsaan menurut rekayasa pendukung kebudayaan dominan melalui kekuasaan politik dan ekonomi: dan

4. Kebudayaan kebangsaan dibentuk dari unsur-unsur kebudayaan asing yang modern dalam mengisi 
kekosongan dan ketidaksepakatan dari berbagai kebudayaan daerah (Garna, 2008)

Jadi budaya lokal adalah warisan kebudayaan yang berlaku dan dimiliki tiap daerah atau suku bangsa. Indonesai dikenal kaya akan corak ragam budaya yang tersebar di berbagai wilayah. Jenis ragam budaya tersebut tercermin dalam seni, adat istiadat, kepercayaan, tradisi, upacara adat, pakaian adat, makan khas daerah, stratifikasi sosial dan lain-lain.

\section{PENGEMBANGAN KREATIVITAS MAHASISWA}

Mahasiswa adalah orang yang belajar di perguruan tinggi (KBBI, 2007). Mahasiswa adalah sebuah elemen dari bangsa ini yang tidak bisa di pisahkan dari kemajuan maupun kemunduran bangsa, kita tahu mahasiswa hanyalah sekelompok orang yang beruntung dan diberi kesempatan lebih dari masyarakat lainnya karena tidak semua rakyat bangsa ini bisa merasakan menjadi mahasiswa.

Kreativitas diartikan sebagai penggunaan imaginasi dan kecerdikan untuk mencapai sesuatu atau untuk mendapatkan solusi yang unik dalam mengatasi persoalan (Susanto,1999). Kreatif bukan bawaan dari lahir melainkan sesuatu yang dapat diciptakan dan dilatih dengan memberikan stimulus atau pancingan kepada otak. Permainan, atau membuat gambar-gambar dapat merangsang otak untuk berpikir kreatif. Dengan berlatih berpikir kreatif, maka inspirasi untuk melakukan, membuat, dan menciptakan sesuatu terbuka lebar sehingga dapat menghasilkan sesuatu yang inovatif.

Hal utama yang diperlukan untuk mengasah dan mengembangkan kreativitas adalah menyiapkan otak untuk selalu terbuka menerima impuls atau rangsangan dari luar. Karena otak itu luar biasa hebatnya, sehingga sangat disayangkan jika tidak menggunakannya semaksimal mungkin. Setiap peristiwa, pengalaman hidup, bahkan hal-hal kecil yang terjadi dan ada disekitar kita dapat digunakan untuk mengembangkan kreativitas. Selain itu telah tersedia produk-produk yang dapat digunakan untuk meningkatkan dan mengembangkan kreativitas seseorang.

Munandar mengatakan beberapa pengertian kreativitas yaitu sebagai berikut :

a. Kreativitas adalah kemampuan untuk membuat kombinasi baru berdasarkan data, informasi atau unsur-unsur yang ada.

b. Kreativitas (berpikir kreatif atau berpikir divergen) adalah kemampuan berda-sarkan data atau informasi yang tersedia, menemukan banyak kemungkinan jawaban terhadap suatu masalah yang penekanannya pada ketepatgunaan dan keragaman jawaban.

c. Secara operasional kreativitas dapat dirumuskan sebagai kemampuan yang mencerminkan kelancaran, keluwesan (fleksibilitas), orisinal dalam berpikir, dan kemampusan untuk mengelaborasi (mengembangkan, memperkaya, mem-perinci) suatu gagasan (Munandar, 1995).

Proses kreativitas mahasiswa dalam mengembangkan gagasan dapat dilihat melalui :

a. Kelancaran, sebagai kemampuan untuk mencetuskan banyak gagasan, jawaban, penyelesaian masalah, atau pertanyaan, memberikan banyak cara atau saran untuk melakukan berbagai hal, dan selalu memikirkan lebih dari satu jawaban.

b. Keluwesan, sebagai kemampuan untuk: 1) menghasilkan gagasan, jawaban atau pertanyaan yang bervariasi, 2) dapat melihat masalah dari sudut pandang yang berbedabeda, 3) mencari banyak alternatif atau arah yang berbeda-beda, dan 4) mampu mengubah cara pendekatan atau cara pemikiran . 
c. Keaslian, sebagai kemampuan untuk: 1) melahirkan ungkapan yang baru dan unik, 2) memikirkan cara yang tidak lazim untuk mengungkapkan diri, dan 3) mampu membuat kombinasi-kombinasi yang tidak lazim dari bagian-bagian atau unsurunsur.

d. Keterperincian, kemampuan untuk dapat mengembangkan suatu gagasan, merincinya sehingga menjadi lebih menarik.(Munandar,1995)

Kemampuan kreatif adalah kemampuan menciptakan gagasan, mengenal kemungkinan alternatif, melihat kombinasi yang tidak diduga dan memiliki keberanian untuk mencoba sesuatu yang tidak lazim. Atau dengan kata lain kreativitas mahasiswa adalah kemampuan untuk memberikan gagasangagasan baru yang dapat diterapkan dalam pemecahan masalah. Sementara Semiawan menegaskan bahwa; "Kreativitas adalah kemampuan untuk menciptakan sesuatu yang baru, ciptaan itu tidak perlu seluruhnya produk baru mungkin saja gabungannya, kombinasinya sedangkan unsur-unsurnya sudah ada sebelumnya. (Semiawan, 1990)

Dari pendapat para ahli tersebut, dapat disimpulkan bahwa kreativitas adalah kemampuan berpikir dalam mengembangkan ide kemudian mengkombinasikannya hingga didapatkan produk baru, orisinil dan tepat guna, berdasarkan unsur-unsur yang sudah ada sebelumnya. Oleh karena itu mahasiswa yang memiliki kreativitas yang tinggi akan mampu menciptakan ide dan gagasan berupa karya seni.

Berdasarkan teori tersebut maka dapat ditarik kesimpulan tentang indikator-indikator pengembangan kreativitas mahasiswa, dalam hal ini merujuk kepada pendapat Munandar, yaitu :

1. Memiliki rasa ingin tahu yang luas. Rasa ingin tahu yang luas mendorong seseorang untuk mengeksplorasi berbagai kemungkinan yang menghambat kehidupannya atau yang dirasakan adanya kesenjangan dalam kehidupannya. Rasa ingin tahu yang luas adalah selalu terdorong untuk mengetahui lebih banyak, selalu memperhatikan objek dan situasi yang baru, peka dalam pengalaman dan ingin mengetahui/meneliti. Mahasiswa yang kreatif memiliki rasa ingin tahu yang luas.

2. Percaya diri

Kepercayaan diri adalah keyakinan yang dimiliki seseorang tentang kemampuan yang ada pada dirinya sehingga menimbulkan keberanian untuk melakukan tindakan dalam meningkatkan prestasinya. Jika dikaitkan pengertian kepercayaan diri mahasiswa dalam mencintai budaya lokal adalah kepercayaan mahasiswa akan kemampuan dirinya untuk dapat mencintai budaya lokal dengan menampilkan budaya lokal itu melalui prestasi.

3. Bebas dalam berekspresi Untuk meningkatkan kreativitas mahasiswa dalam mencintai budaya lokal, mereka tidak hanya mengenal budaya saja, tetapi mahasiswa dapat mengungkapkan dan mengembangkan ide atau gagasannya secara bebas dalam suatu bentuk karya yang nyata tanpa rasa takut. Berdasarkan hal di atas, maka dalam proses mencintai budaya lokal, mahasiswa akan mengungkapkan ide dan ekspresi dalam mengembangkan budaya lokal, sehingga budaya lokal itu bisa menjadi sebuah ekspresi diri dan menambah prestasi mereka di 
ajang-ajang seni dan budaya di kampus.

\section{REVITALISASI NASKAH SYAIR DALAM PENGEMBANGAN KREATIVITAS MAHASISWA}

Mahasiswa di perguruan tinggi berasal dari kebudayaan yang beragam. Mahasiswa itu akan mencerminkan ciri khas dari daerah mereka masing-masing. Seperti mahasiswa berasal dari Sumatera Barat akan berbahasa minang. Mahasiswa yang berasal dari daerah, tentunya mereka sudah mengenal budaya mereka sendiri. Seperti mahasiswa dari sumatera barat, mereka sudah mengenal dengan pantun, lagu-lagu minang ataupun syair-syair yang ada di budaya mereka. Namun dengan kedatangan mereka ke subuah daerah lain, mereka melupakan budaya mereka, karena terkontaminsasi dengan budaya yang ada di tempat mereka kuliah.

Permasalah di atas bisa diatasi dengan cara revitalisasi budaya lokal mereka. Program-program kerja yang ada di organisasi intra kampus harus kembali dibenahi khususnya di bidang seni dan budaya. Program yang dibuat hendaknya seni dan budaya dari seluruh daerah tempat asal mahasiswa, sehingga dengan adanya program budaya daerah masingmasing, mereka akan lebih mengenal dan mencintai budaya mereka masingmasing.

Di perguruan tinggi diajarkan berfikiran kreatif, dan belajar cara memecahkan masalah yang ada didaerah lingkungan sekitar. Terdapat beberapa organisasi baik intra maupun ekstra kampus, mereka berkumpul di organisasi tersebut dari berbagai daerah dan budaya yang berbeda pula, sehingga mereka bisa membahas budaya-budaya mereka dan saling mengenalkan budaya masingmasing. Dengan cara itu mereka sudah mencoba ke arah pengembangan kreativitas seni yang berbasis budaya lokal.

Organisasi kampus merupakan sebuah wadah dalam mengembangkan bakat dan minat mahasiswa. Salah satu pengembangan bakat dan minat itu adalah pengembangan bakat dan minat bidang seni. Bidang seni yang terdapat dalam organisasi kampus, cenderung mengembangkan seni-seni modern bahkan cenderung meniru seni dari Barat. Seperti, mahasiswa lebih menyukai lagulagu barat, tarian atau dance modern, drama-drama dari Barat (contoh : korea).

Hal itu menunjukkan bahwa pengembangan kreativitas mahasiswa sangat jauh dari budaya lokal. Oleh karena itu perlu solusi supaya mereka mencintai budaya lokal dengan cara memasukkan program pengembangan budaya lokal ke dalam program kerja organisasi kampus, khususnya di bidang seni.

Naskah syair merupakan salah satu kekayaan budaya lokal bangsa Indonesia. Naskah syair yang ada di Indonesia sangat banyak sekali. Seperti naskah syair yang terdapat di Riau adalah Naskah Syair Raksi dan Syarah Hari Bulan yang sudah dialih abahasakan oeh Hasan Junus dan Drs Elmustian Rahman, MA. Isi dari naskah itu bisa dijadikan sebuah bentuk kreatifitas. Kreativitas yang bisa dikembangkan adalah dijadikan sebuah drama yang mengandung ajaran-ajaran tentang perjodohan. Hal itu bisa terilihat dari beberapa bait syairnya yaitu :

Inilah jodoh bersama setia

Kasih dan Sayang kepada manusia

Orang melihat bersuka ria

Tiada memperbuat pekerjaan aniaya. 
Jika esa bersama tiga

Demikian itu berbaik juga

Tetapi menaruh syak dan sangka

Bercerai juga, tiada akan leka (Haji Ahmad, 2002)

Sebenarnya Syair Raksi dan Syarah Hari Bulan itu mempunyai banyak bait syair. Yang disebutkan di atas hanya sebagai contoh saja, yang bisa dikembangkan menjadi beberapa kreatifitas. Syair-syair itu bisa dijadikan lagu, bahkan bisa dikembangkan menjadi drama. Bila ditelusuri semua syair-syair tersebut bisa dikembangkan menjadi syair lagu, drama bahkan lagu bisa dipadu dengan musik-musik berirama melayu. Dengan adanya pengembangan kreativitas budaya lokal melalui naskahnaskah syair, ini sudah merupakan sebuah solusi dalam mencintai budaya lokal.

Oleh karena itu, program-program kerja yang terdapat di dalam organisasi kampus, hendaknya bisa memasukkan seni mengandung unsur-unsur budaya lokal seperti menjadikan naskah syair sebagai bahan untuk dikembangkan ke dalam program seni. Sehingga seni yang berkembang di kampus juga mengandung seni budaya lokal. Dengan cara tersebut, maka langkah ini sudah merupakan sebuah solusi untuk mencintai budaya lokal sendiri.

Dampak positif lainnya dari program pengembangan seni budaya lokal adalah mahasiswa jadi lebih tahu kebudayaan lokalnya sendiri. Artinya, mahasiswa yang bukan pendatang mengetahui dan ikut mempelajari kebudayaan dari suku diluar daerahnya. Hal ini, dapat mempererat dan membuat para mahasiswa sebagai penerus bangsa sadar akan kekayaan budaya yang dimiliki Indonesia.

\section{SIMPULAN}

Naskah syair yang merupakan salah satu budaya lokal bangsa Indonesia, hendaknya bisa lebih dikembangkan melalui program organisasi kampus. Dengan dijadikannya naskah syair sebagai sebuah seni yang penting dalam pengembangan kreativitas mahasiswa, maka ini sudah merupakan sebuah solusi untuk menciptakan rasa kecintaan mahasiswa terhadap budaya lokal.

\section{UCAPAN TERIMA KASIH}

Peneliti mengucapkan terima kasih kepada pihak-pihak yang telah membantu selama proses penulisan artikel ini. Selain itu, penulis sampaikan terima kasih kepada redaksi Jurnal bahasa \& sastra atas pemuatan artikel ini.

\section{PUSTAKA RUJUKAN}

Abdullah, I. (2006). Konstruksi dan Reproduksi

Kebudayaan. Yogyakarta

: Pustaka Pelajar.

Abdullah, M. (2006). Dekonstruksi Sastra Pesantren. (Filologi, Gender, Filsafat, dan Teologi Islam). Semarang : Fasindo.

Bafadal, F. \& Saefullah, A. (2005). Naskah Klasik Keagamaan Nusantara 1. Jakarta : Depag RI.

Basuki, A, et al. (1989). "Metode Penelitian Sastra Lama". Diktat Kuliah. Semarang : Fakultas Sastra Undip .

Braginsky, V.I. (1998). Tasawuf dan Sastera Melayu: Kajian dan Teks-teks. Jakarta: RUL.

Djamaris, E. (1986). Puisi Indonesia Lama Berisi Nasihat. Jakarta: Depdikbud, Proyek Penerbitan Buku Sastra Indonesia dan Daerah. 
Effendy, T. (2006). Tunjuk Ajar Melayu. Yogyakarta: Balai Kajian dan Pengembangan Melayu.

Garna, J.K. (2008). Budaya Sunda : Melintasi Waktu Menantang Masa Depan. Bandung : Lemlit Unpad.

Haji Ahmad, E. (2002). "Syair Raksi dan Syarah Hari Bulan". (Alih Aksara Bahasa dan Sastra Melayu Riau. Hasan Junus \& Elmustian Rahman). Laporan Projek Pembinaan Bahasa dan Sastra Daerah Riau. Pekanbaru: Dinas Kebudayaan, Kesenian dan Pariwisata Pemerintah Propinsi Riau.

Kuntowijoyo. (2006). Budaya dan Masyarakat. Yogyakarta : Tiara Wacana.

Munandar, U. (1995). Pengembangan Kreativitas Anak Berbakat. Jakarta: Rineka Cipta.

Mulyadi, S.W.R.(1994). Kodikologi Melayu Indonesia. Jakarta : Fakultas Sastra Universitas Indonesia.

Muzzaki, A. (2006). Kesusastraan Arab (Pengantar Teori dan Terapan). Jogjakarta : AR-Ruzz Media.

Nur Berlian, V.A. (2012). "Identifikasi faktor-faktor budaya lokal yang mempengaruhi capaian kinerja pembangunan pendidikan". Jurnal Kebudayaan; Jurnal Penelitian dan pengembangan Kebudayaan Vol. 7 No. 2 November 2012. ISSN 19075561.

Pradopo, R.D. (2005). Pengkajian Puisi : Analisis Strata Norma dan Analisis Struktural dan Semiotik. Jogjakarta : Gajah Mada University Press.

Ranjabar, J. (2006). Sistem Sosial Budaya Indonesia.Bogor :Ghalia Indonesia.

Semiawan, C. (1990). Memupuk bakat dan kreativitas sekolah menengah. Jakarta : Gramedia.

Sunarjo, N. (2001). Analisis Struktural dan Nilai Budaya Syair Bertema Sejarah. Jakarta : Pusat Bahasa Depdikbud.

Tim Penyusun Kamus Pusat Pembinaan dan Pengembangan Bahasa. (2007). Kamus Besar Bahasa Indonesia. (edisi ketiga). Jakarta: Balai Pustaka.

Waluyo, H.J. (1987). Teori dan Apresiasi Puisi. Jakarta: Penerbit Erlangga. 